\title{
Supercooling of Seawater Near the Glacier Front in a Fjord
}

\author{
A. V. Marchenko ${ }^{1}$, E. G. Morozov ${ }^{2} \&$ N. A. Marchenko ${ }^{1}$ \\ ${ }^{1}$ Svalbard University Center, Longyearbyen, Spitsbergen, Norway \\ ${ }^{2}$ Shirshov Institute of Oceanology, Russian Academy of Sciences, Moscow, Russia \\ Correspondence to: E. G. Morozov, Nakhimovskiy pr. 36, Moscow 117997, Russia. E-mail: egmorozov@mail.ru
}

Received: July 14, 2016

Accepted: August 10, 2016

Online Published: December 27, 2016

doi:10.5539/esr.v6n1p97

URL: http://dx.doi.org/10.5539/esr.v6n1p97

\begin{abstract}
We analyze seawater temperature and salinity in the immediate vicinity of the Paulbreen front in Spitsbergen. The CTD-measurements were carried out from ice in winter and from a boat in summer. ADCP profiling was performed near the glacier front from the ice in winter. In winter, we found water with lower salinity than the surrounding water in the fjord at a distance of $15 \mathrm{~m}$ from the glacier front and recorded a low upward water flux near the glacier. Relatively fresh water was found at a depth of 2-4 m near the glacier front in the place where the sea and glacier bed have local depression up to $17 \mathrm{~m}$. Supercooling of the freshened water reached $0.35^{\circ} \mathrm{C}$. We link this phenomenon to a flow of freshwater from under a polythermal glacier. This water becomes overcooled in the seawater with significantly lower temperature and higher salinity.
\end{abstract}

Keywords: supercooling, glacier, CTD, Spitsbergen

\section{Introduction}

In this paper, we analyze the measurements of water properties close to the front of Paulabreen (Paula Glacier) in Spitsbergen and examine the deviation of seawater temperature from its freezing point. Three mechanisms exist that lead to supercooling of water: (1) removal of heat, (2) differences in the diffusion rate between heat and salt, and (3) rapid pressure decrease. The processes that occur in the water near glaciers frequently lead to water supercooling.

Some decades ago, the special term "glaciohydraulic supercooling" was introduced (Röthlisberger, 1972). The author reports that glaciohydraulic supercooling is a process that occurs when the pressure melting point of water ascending the adverse slope of a subglacial overdeepening rises faster than the water is heated by viscous dissipation resulting in water remaining liquid below $0^{\circ} \mathrm{C}$. In other words, glaciohydraulic supercooling occurs when water rapidly ascends to smaller depths and cools to the temperature needed for freezing. Upwelling and cooling of water with salinity lower than that in the surrounding waters is a particular case of this phenomenon. Transport of water from the region of high pressure to the region of low pressure without equalization of the water's internal energy can lead to freezing (Creyts and Clarke, 2010). Cook et al. (2006) analyze the processes in the basement of glaciers and state that glaciohydraulic supercooling allows water to remain liquid at temperatures lower than the freezing point. They write: Glaciohydraulic supercooling is a process that allows water at the base of a glacier to remain liquid at a temperature below its freezing point in response to the geometry of water flow and subglacial pressure.

Conditions for seawater supercooling arise when water is cooled to the freezing point in situ due to the contact with ice in deep water. If the water then ascends to the depths where the local freezing temperature is higher, the water appears at a temperature below the freezing point (Stevens et al., 2010) because the freezing temperature decreases when pressure decreases. It has been shown that floating glaciers over a shelf can be sources of supercooled water (Debenham, 1965; Jeffries and Weeks, 1992). Such a phenomenon was found in the data from CTD casts (Stevens et al., 2010, Fig. 6) in seawater close to a glacier: the seawater was $0.01^{\circ} \mathrm{C}$ cooler than its freezing point under the floating ice of a glacier tongue in Antarctica. We think that in this case two mechanisms are responsible: fast cooling and fast upward motion to lower pressure.

If there are no nucleation centers, the supercooled water remains liquid and then platelets and frazil ice crystals are formed. Observations of this phenomenon are described in (Dmitrenko et al., 2010; Robinson, 2010). On the basis of laboratory studies, Brewster and Gebhart (1994) report strong supercooling of water with oceanic salinity $35 \mathrm{psu}$. This water supercooled by as much as $5.0^{\circ} \mathrm{C}$ before it began to freeze. Moreover, this 
supercooled water was found far from the cooling surface. Lawson et al. (1998) describe field measurements made near the Matanuska Glacier in Alaska and suggest a model wherein glaciohydraulic supercooling is an important mechanism for glacier ice growth. In their model, ice crystals accrete from supercooled water, which flows through the drainage system of the glacier. Such water contains suspended filaments: ice spicules.

Supercooling is frequently observed in polynyas (Skogseth et al., 2009; Dmitrenko et al., 2010). The water can be supercooled by as much as $0.01-0.02^{\circ} \mathrm{C}$. Supercooling results in ice formation that occurs initially throughout the surface water layer in the form of small millimeter-scale crystals, called frazil ice crystals that float slowly to the surface.

Laboratory experiments on frazil ice formation in the upper low saline water layer cooled from below by a more saline cold water layer are described in (Zatsepin and Golovin, 2001). The authors report that frazil ice production increases when both layers are in the turbulent motion. A similar effect of ice freezing below the water surface was described by Nansen (1897) in the sea when he observed a freshwater layer in the sea over cold saline sea waters at a temperature close to freezing.

Błaszczyk et al., (2009) present a classification of Svalbard glaciers and the current state of tidewater glaciers (having contact with the ocean) including Paulabreen. Their classification is an extension of the inventory by Hagen et al., (1993). Jiskoot et al., (2000) analyzed the distribution of surge-type glaciers in Svalbard. They show that a polythermal regime and fine-grained bed facilitate the surge potential of Svalbard glaciers.

Several papers are dedicated to the water properties near a vertical ice wall. Foldvik and Kvinge (1974) considered a thermohaline convection of conditional instability in the ocean near the ice shelf released by the formation of ice crystals in the ascending water. A paper by Huppert and Turner (1980) considers a laboratory experiment when water originating from ice melting in stratified fluid forms a step structure. A similar structure is formed when water with a vertical gradient of salinity is cooled at a vertical wall. Laboratory experiments reported in (Josberger and Martin, 1981) study the convection generated in polar oceans when a fresh-water wall melts in salt water of different uniform far field temperature and salinity. Field measurements near the Erebus Glacier tongue in Antarctica were considered in (Jacobs et al., 1981). A vertically stable step structure was observed in the water column $400 \mathrm{~m}$ thick from the surface to the bottom.

The objective of this paper is to describe the measurements that recorded supercooling of water in the fjord near the front of Paulabreen in Spitsbergen and give our interpretation of the results. These measurements represent the case when the surrounding water near an ice wall is cooler than fresh water from the glacier, which flows into almost freezing surrounding water. To our knowledge, these are the first records of such a strong supercooling phenomenon in seawater measured in the field experiments very close to the glacier front.

\section{Data of Measurements Near the Glacier Front}

Measurements of water properties were carried out in Spitsbergen in Rinders Bay near Paulabreen in 2010-2015 (Fig. 1a). High resolution satellite image of Paulabreen made in 2011 provided by the Norwegian Polar Institute is shown in Fig. 1b. Yellow points in Fig. 1b show the locations of CTD profiling in August 2011 performed from the research vessel "Viking Explorer". A 3-meter draft of the boat did not allow us to approach closer to Paulabreen front. Points of sea depth measurements near the front of Paulabreen performed from sea ice in March 2013 are shown in Fig. 2 with red dots. Locations of the red dots relative to the glacier front in Fig. 2 can differ from their actual positions since the satellite image was adjusted to the map manually, while the point coordinates on the map correspond to their GPS coordinates measured in the field. The sea depth along the glacier front is shown in Fig. 3. The greatest concavities of the glacier front were found in the deepest places along the front of Paulabreen. 


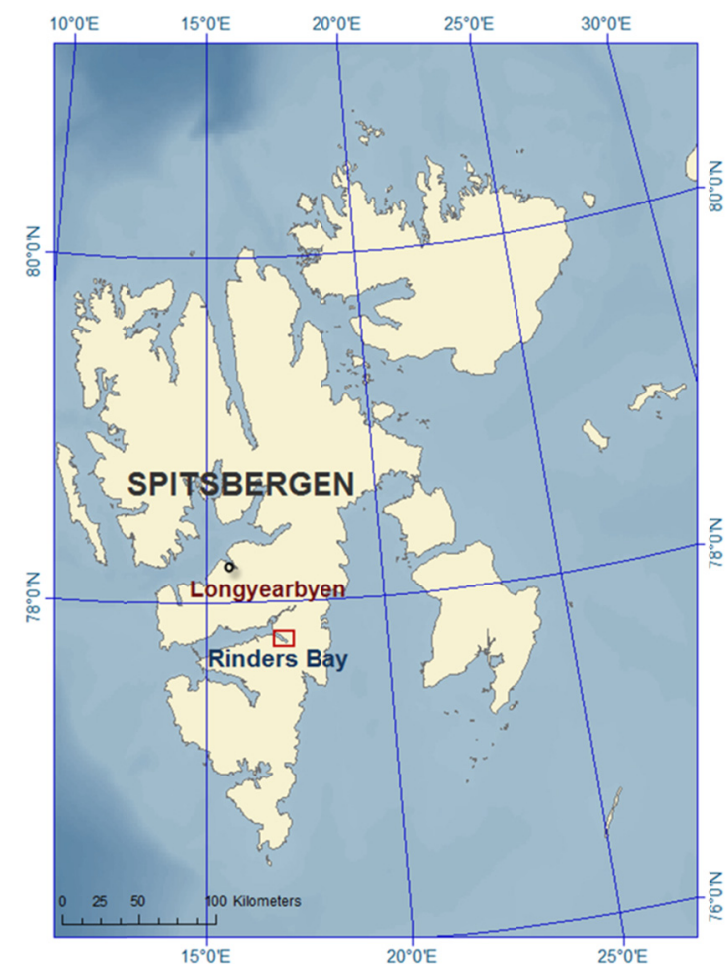

a

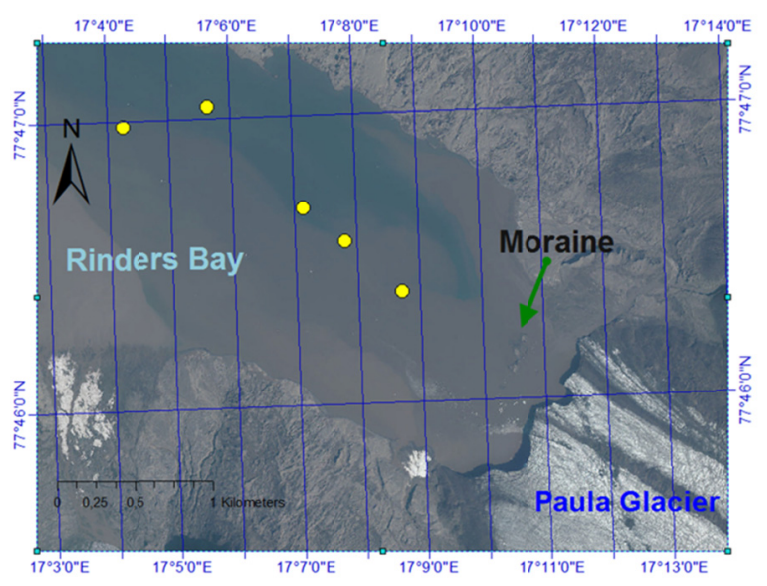

$\mathrm{b}$

Figure 1. Location of Rinders Bay in Spitsbergen (a). Satellite image of Rinders Bay (NPI, 2011) (b). Yellow dots indicate locations of CTD-measurements in August 2011. The moraine is a shallow place near the glacier

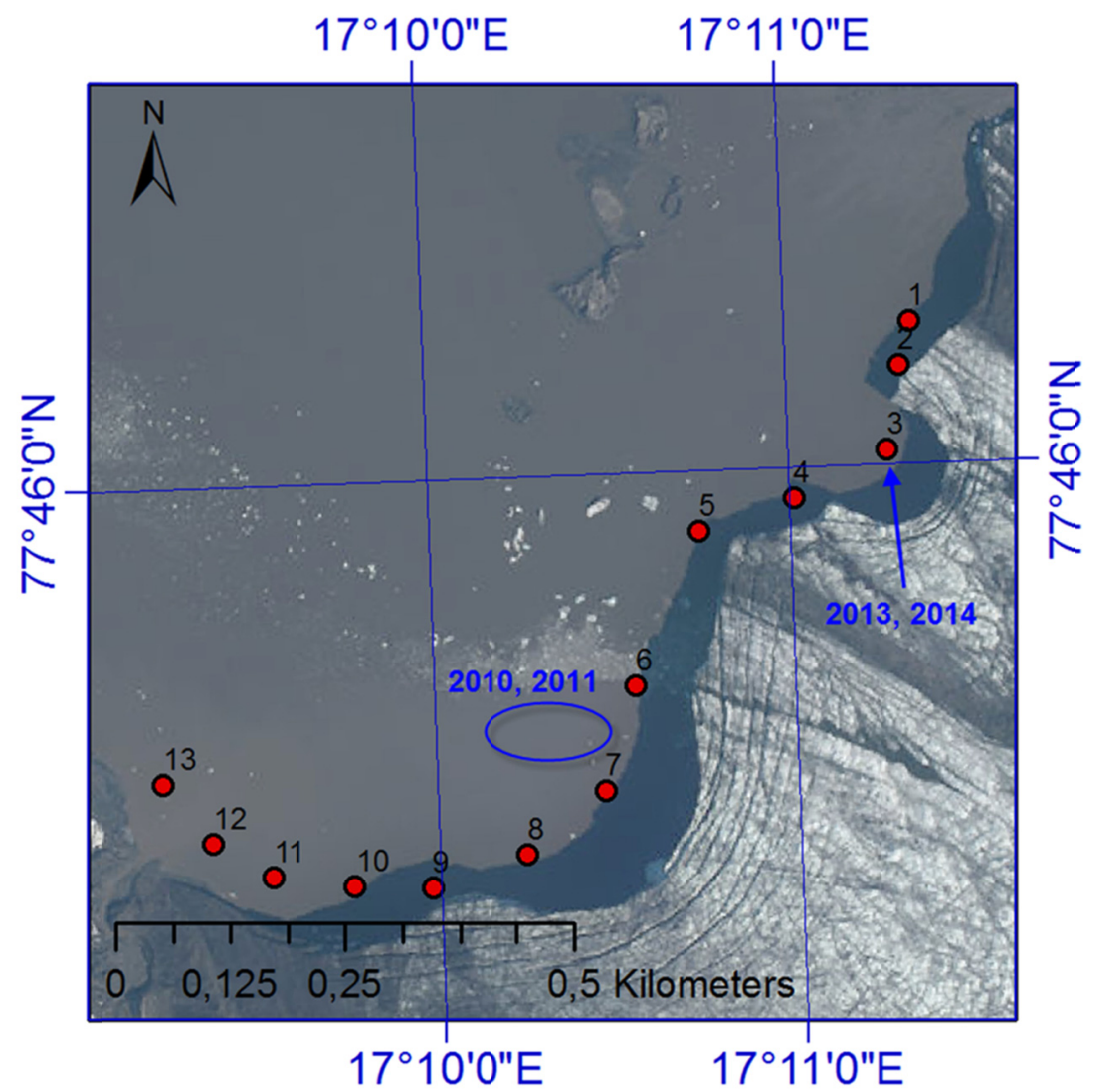

Figure 2. Locations of the field works near Paulabreen front 


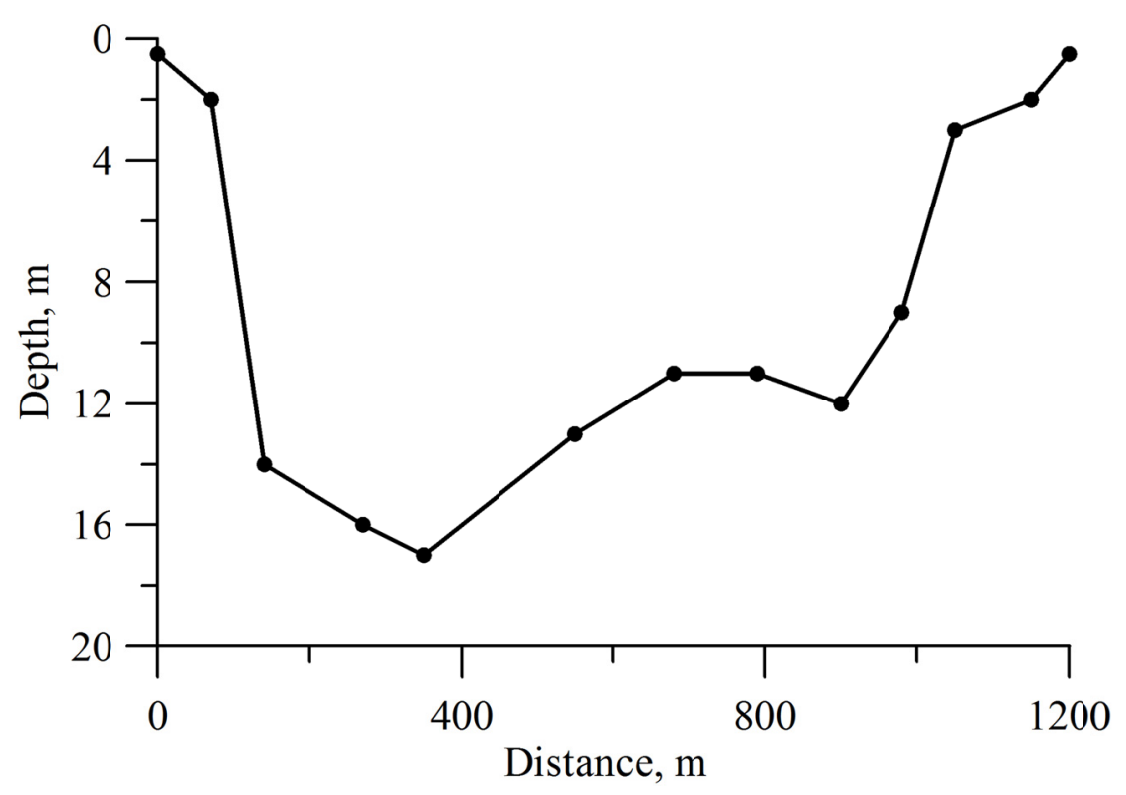

Figure 3. Depth near Paulabreen front. Distance is laid off along the wall of the glacier. Thirteen points of measurements are related to the locations shown in Fig. 2 with red dots in the direction from northeast to southwest

The dates of the field measurements and the equipment we used are shown in Table 1. Measurements in the winter time of 2010 and 2011 were carried out at a distance of 100-200 m from the glacier front without fixing the GPS positions of the points where the measurements were performed. Their locations are within the blue ellipse in Fig. 2. The GPS coordinates of the points where CTD profiling was performed in 2013 and CTD and ADCP profiling was performed in 2014 are the same (Fig. 2). The glacier wall was located at a distance of 10-15 meters from the point of measurements in 2013. The glacier retreated over a distance of about $100 \mathrm{~m}$ from the same point of measurements in 2014.

Table 1. Dates of measurements and instruments

\begin{tabular}{llllll}
\hline $\begin{array}{l}2010 \\
\text { March }\end{array}$ & 2011 & 2011 & 2013 & 2014 & 2015 \\
$10-11$ & Aebruary 23-24 & August 31 & March 12 & March 30 & March 18-19 \\
\hline TS EBA & SBE-37SM, & SBE-19plus & SBE-19plus & SBE-19plus V2 & SBE-19plus \\
& SBE-39 & V2 & V2 & $\begin{array}{l}\text { ADCP RDI 1200 } \\
\text { kHz }\end{array}$ & V2 \\
& & & & \\
\hline
\end{tabular}

On February 23-24, 2011, the ice was $60 \mathrm{~cm}$ thick and covered with a $15 \mathrm{~cm}$ snow layer. The air temperature was $-15^{\circ} \mathrm{C}$. In March 2013 and 2014 the ice was $100 \mathrm{~cm}$ thick and covered with a $10 \mathrm{~cm}$ snow layer. The air temperature was $-25^{\circ} \mathrm{C}$ on March 12, 2013, and $-10^{\circ} \mathrm{C}$ on March 30, 2014. The ice surface was flat and not deformed in all field campaigns in 2010-2014. In 2013 and 2014 the ice thickness near the entrance to Rinders Bay at the distance of about $15 \mathrm{~km}$ from the glacier front was $50-60 \mathrm{~cm}$, i.e. the sea ice near Paulabreen was thicker by $40-50 \%$. Similar effect of substantial increase in the ice thickness by $40-50 \%$ over $10 \mathrm{~km}$ distance to the glacier front was also observed near the Tuna Glacier in Spitsbergen in 2010 and 2011 (Marchenko et al, 2011).

Systematic measurements of the ice thickness were performed in Svea Bay and around Kapp Amsterdam coal quay located at distance of $25 \mathrm{~km}$ and $20 \mathrm{~km}$, respectively, from Paulabreen. Svea Bay is located in the end of the Van Mijen Fjord where sea depth is shallower than $10 \mathrm{~m}$; the heat fluxes from the sea are very small and do not exceed 1-3 W/ $/ \mathrm{m}^{2}$ (Marchenko et al., 2009). Measurements of the ice thickness in Svea Bay performed during flexural strength tests on the ice beams show ice thickness less than $0.7 \mathrm{~m}$ in March 2012 (Karulina et al., 2013) and less than $0.8 \mathrm{~m}$ in March 2013. Kapp Amsterdam coal quay is located on the opposite shore of the Van Mijen 
Fjord relative to Rinders Bay. Heat fluxes from the sea to the ice measured near Kapp Amsterdam coal quay are also very small (Bogorodsky et al, 2014). According to (Hoyland, 2009) the maximum ice thickness measured near Kapp Amsterdam was less than $0.7 \mathrm{~m}$ in February-April 2000-2002. The sea depth between the Kapp Amsterdam and Rinders Bay can reach $60 \mathrm{~m}$ in the central part of the fjord, and the influence of the heat flux from the sea could be greater. Ice thickness measurements performed in this region in March 2013 demonstrated spatial variations of ice thickness between $50 \mathrm{~cm}$ and $60 \mathrm{~cm}$.

Water temperature near the glacier front was measured with thermistor string (EBA Engineering, Edmonton, Canada) on March $10-11,2010$. The accuracy is $0.01^{\circ} \mathrm{C}$ and the resolution is $0.001^{\circ} \mathrm{C}$. The distance between thermistors was $1 \mathrm{~m}$ and $1.5 \mathrm{~m}$ between three end thermistors. Results of measurements performed with a $2 \mathrm{~min}$ sampling time interval are shown in Fig. 4a (depths 1-5 m) and in Fig. 4b (depths 6-10 m). Synchronous variations in the temperature within $0.05^{\circ} \mathrm{C}$ are seen on the graphs. Water temperature at the bottom at a depth of $10 \mathrm{~m}$ is slightly lower than the surface temperature of the water. Temperature measurements performed using the SBE-39 recorder (the accuracy is $0.002^{\circ} \mathrm{C}$ and resolution is $0.0001^{\circ} \mathrm{C}$ ) on February 23, 2011 show smaller water temperatures in the range of shallower sea depth $(\sim 5.4 \mathrm{~m})$ (Fig. $4 \mathrm{c})$.
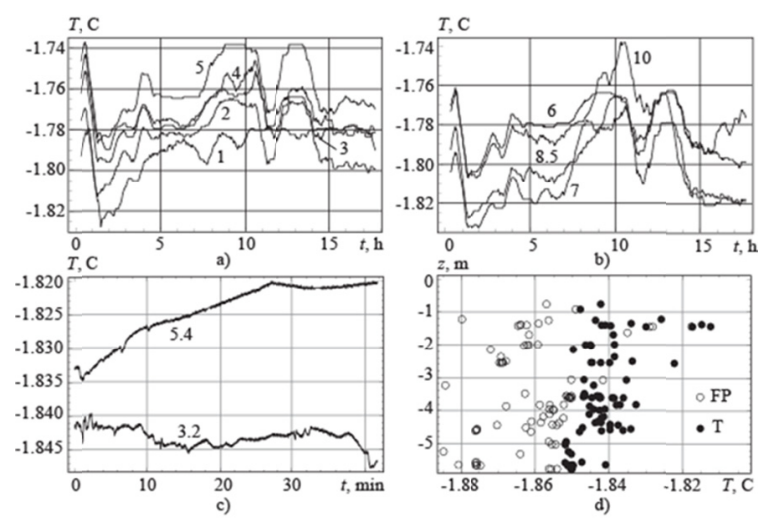

Figure 4. Water temperature versus time on March 10-11, 2010 (a,b) and on February 23, 2011 (c). Location depth of thermistors is shown by numbers. Temperature profile (T) and water freezing points (FP) calculated from the CTD data were collected on February 24, 2011 (d)

The CTD profiling performed in Rinders Bay from the research vessel "Viking Explorer" on August 31, 2011, shows positive water temperatures varying from $+1^{\circ}$ to $+5^{\circ} \mathrm{C}$. In summer, strong vertical gradients of temperature, salinity, and density exist at a depth of a few meters due to warming at the surface and freshwater flow from the coast. This layer prevents vertical motions of water masses. Figures 5 and 6 demonstrate sections of salinity and temperature along the axis of Rinders Bay constructed from the CTD measurements at the locations shown by the yellow dots in Fig. 1b. The general features of these distributions are temperature decrease with the distance from the glacier and with the depth. Salinity increases with the depth and at a distance of several miles from the glacier it exceeds 34 psu (not shown in the figure). The jumps in the bottom topography are related to the fact that the section line did not coincide with the lowest depression of the fjord (thalweg line of the valley or waterway).

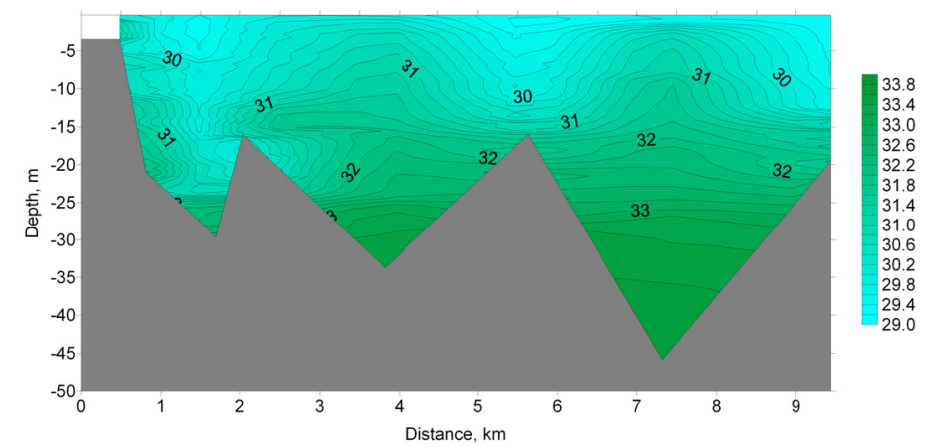

Figure 5. Salinity distribution versus distance from Paulabreen normal to the front on August 31, 2011. Grey color denotes bottom 


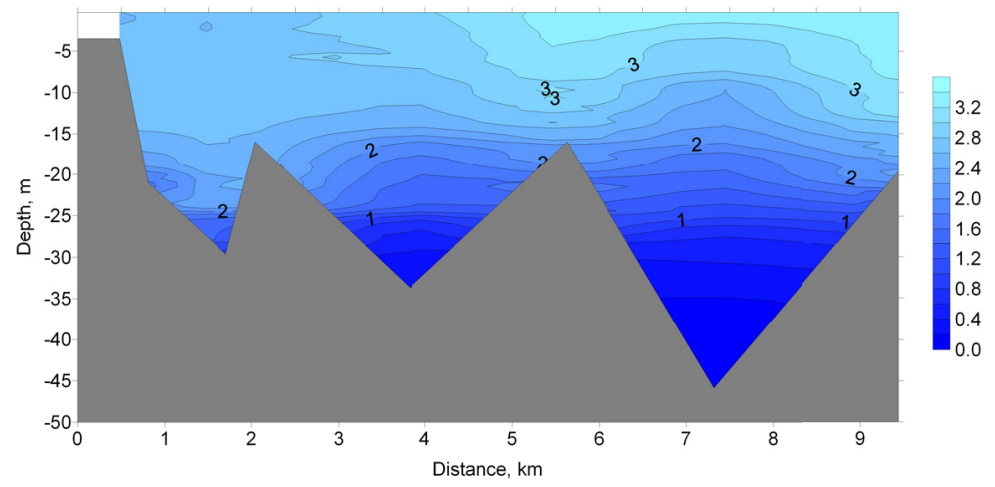

Figure 6. Temperature distribution versus distance from Paulabreen normal to the front on August 31, 2011. Grey color denotes bottom

In 2013 and 2014, CTD profiling near Paulabreen was performed with SBE-19plus V2 CTD-profiler. The instrument was calibrated by the SBE manufacturing company before the winter field season in the summer of 2013. Field intercalibration between available instruments (SBE-37SM and SBE-39) before and after the measurements demonstrated that the differences between the instruments were within the limits stated by the manufacturer: $0.005^{\circ} \mathrm{C}$ (temperature) and $0.0005 \mathrm{~S} / \mathrm{m}$ (conductivity), which results in 0.005 psu accuracy in salinity.

The SBE-19 profiler was transported to the place of measurements on sledges in a plastic box with internal thermal insulation and heater working from an automobile battery. The heating was necessary since in cold weather the sensor would be cooled during the transportation over $25 \mathrm{~km}$ from the closest settlement in Svea, and the sea water pumped through the instrument duct with sensors could be frozen. Before profiling the instrument was adjusted to the water temperature during 10 minutes. CTD profiling was performed at several locations in the Van Mijen Fjord near the entrance to Rinders Bay and near Paulabreen front. Figure 7 shows that sea water near the glacier is fresher, warmer and has lesser density than in the Van Mijen Fjord. Water characteristics have much stronger vertical variability near the glacier as compared to the fjord.

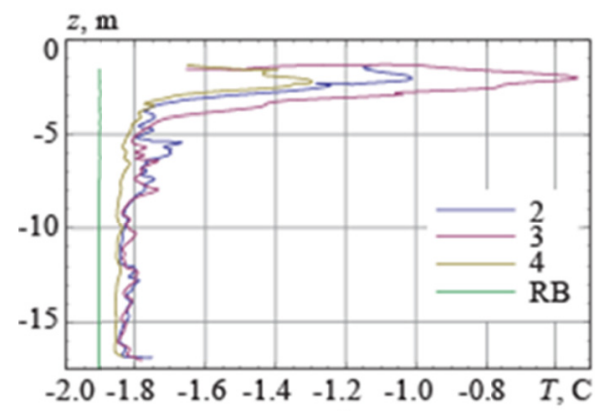

a)

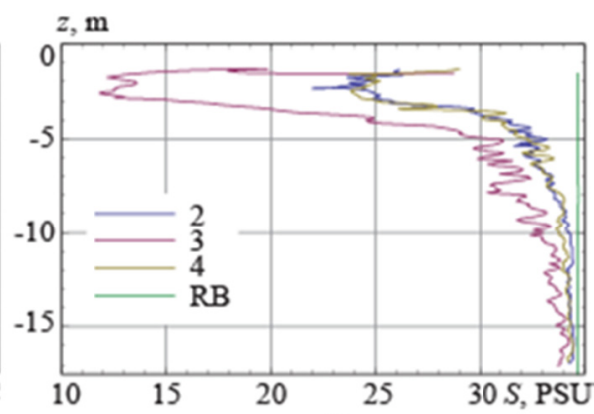

b)

Figure 7. Water temperature (a) and salinity (b) profiles measured on March 12, 2013 (downcasts 2, 3 and 4). The green line corresponds to background vertical distributions measured at the entrance to Rinders Bay (RB) at a distance of $15 \mathrm{~km}$ from the glacier

Four downcasts and upcasts of CTD profiling were performed at a distance of 10-15 m from the glacier wall on March 12, 2013 (Table 2). The depth at the point of measurements was $17 \mathrm{~m}$. The SBE sensor was placed in the water through the drilled hole where we observed great amount of slush. It was impossible to remove all slush from the hole after the drilling since it has been continuously forming in the surface layers below the ice. The SBE sensor was very warm when it was taken out of the plastic box and it could influence measurements in the first cast. Therefore the results of CTD profiling are shown in Fig. 7 for only for downcasts 2-4 after adjusting the instrument temperature to the sea water. One can see that the water has smaller salinity and higher temperature in the surface layers. Temperature and salinity profiles below $7 \mathrm{~m}$ depth were more or less the same during downcasts and upcasts 2-4. Above this level downcasts show higher temperature and lower salinity than upcasts. 
Table 2. Duration (in seconds) of casts in CTD profiling on March 12, 2013

\begin{tabular}{lllll}
\hline Casts & 1 & 2 & 3 & 4 \\
\hline Down & 35 & 70.75 & 76.25 & 51.25 \\
\hline Up & 42.5 & 24.25 & 27.5 & 82.5 \\
\hline
\end{tabular}

Water properties near the glacier strongly differ from the waters in the fjord far from the glacier. Vertical profiles of deviations from the background values are seen in Fig. 7. At a depth of 2-3 $\mathrm{m}$ the deviations of temperature exceed $0.6^{\circ} \mathrm{C}$ and salinity deviations are greater than $11 \mathrm{psu}$. Near the glacier at a depth of $2-4 \mathrm{~m}$ their distribution clearly deviates from the background distribution. In this surface water, we found higher temperatures (up to $-1.29^{\circ} \mathrm{C}$ ) and lower salinity up to $23.7 \mathrm{psu}$. This was accompanied by unstable vertical distribution of density. The background distributions of temperature, salinity, and density in Rinders Bay at a distance of $15 \mathrm{~km}$ from the glacier do not show such strong variations.

Two CTD downcasts and upcasts were performed on March 30, 2014, at the point with the same GPS coordinates as on March 12, 2013. The depth at the point of measurements was $17 \mathrm{~m}$. The results of CTD profiling are shown in Fig. 8 for downcasts 1 and 2. One can see that the water has smaller salinity and higher temperature in surface layers, and the water temperature and salinity are higher than in 2013 . The lowest salinity was observed in the surface water layer above $5 \mathrm{~m}$ depth.
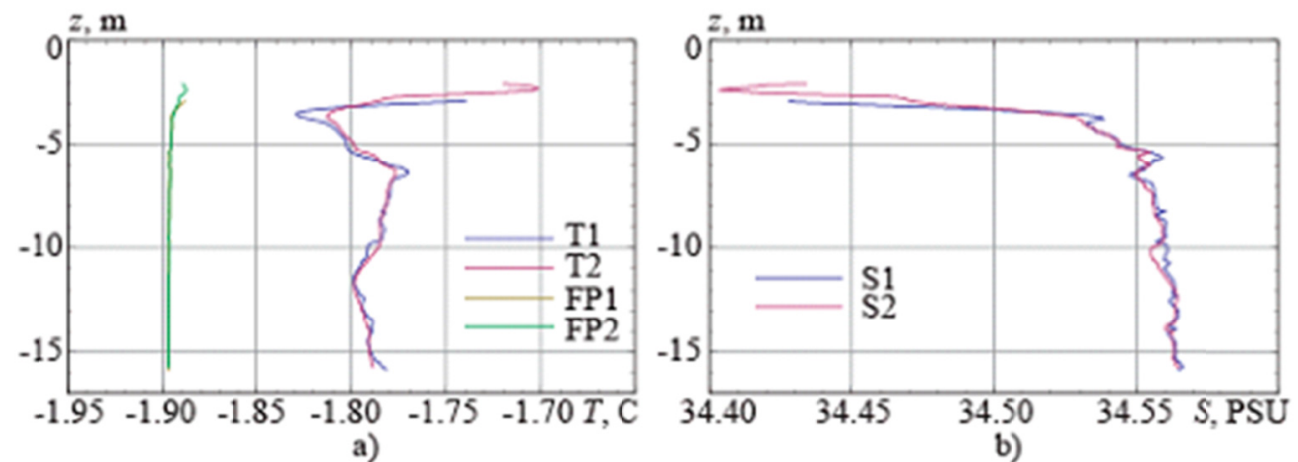

Figure 8. Water temperature (a) and salinity (b) profiles measured on March 30, 2014: downcasts 1 and 2.

Freezing points profiles FP1 and FP2 are calculated from the salinity data (downcasts 1 and 2)

Measurements of the vertical profile of water velocity were performed with ADCP RDI Sentinel $1200 \mathrm{kHz}$ after the CTD profiling on March 30, 2014. The ADCP was deployed in the down-looking mode with ensemble interval $2 \mathrm{~min}$, bin size $0.5 \mathrm{~m}$ and 45 pings per ensemble (Fig. 9a). The measurements were performed in two stages. In the first stage, the ADCP was deployed in the position shown in Fig. 9a during 20 min. Then in the second stage, the ADCP was displaced down over a distance of $10 \mathrm{~m}$ and measurements were performed during the next $15 \mathrm{~min}$. Velocity measurements in the first and second stages including respectively 21 bins and 18 bins are shown in Fig. 9a. Vertical profiles of mean vertical $\left(V_{z}\right)$ and absolute $(V)$ velocities averaged over the measurement intervals $(20 \mathrm{~min}$ in the first stage and $15 \mathrm{~min}$ in the second stage) are shown in Fig. 9b. The vertical velocities are directed upward at depths below $10 \mathrm{~m}$, and their absolute values are below $5 \mathrm{~mm} / \mathrm{s}$. The absolute values of the horizontal velocities vary between 10 and $20 \mathrm{~mm} / \mathrm{s}$. Vertical profiles of mean directions of the horizontal velocities are shown in Fig. 9c. The mean direction of the horizontal velocity over entire water column is to the west, i.e. the water flux is directed out of the concave surface of the glacier wall (Fig. 2). 


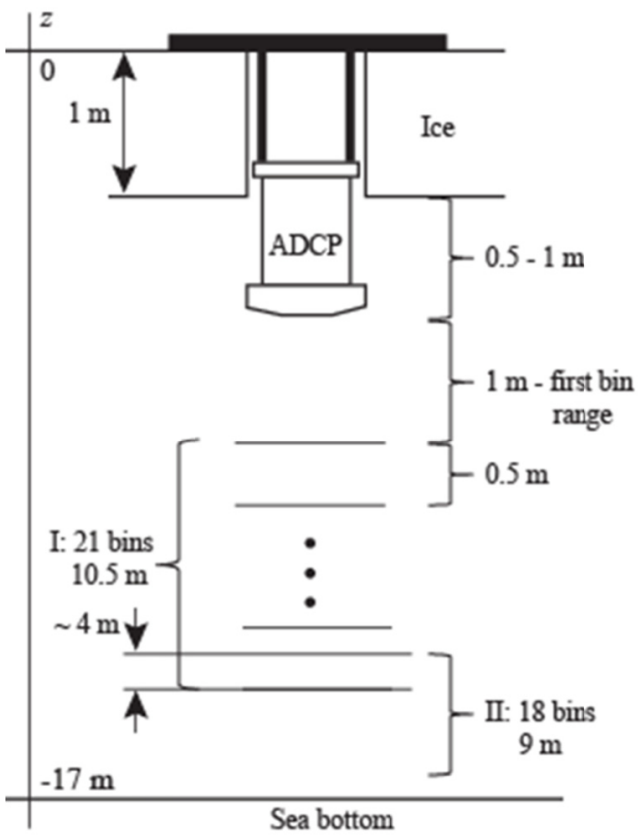

a)
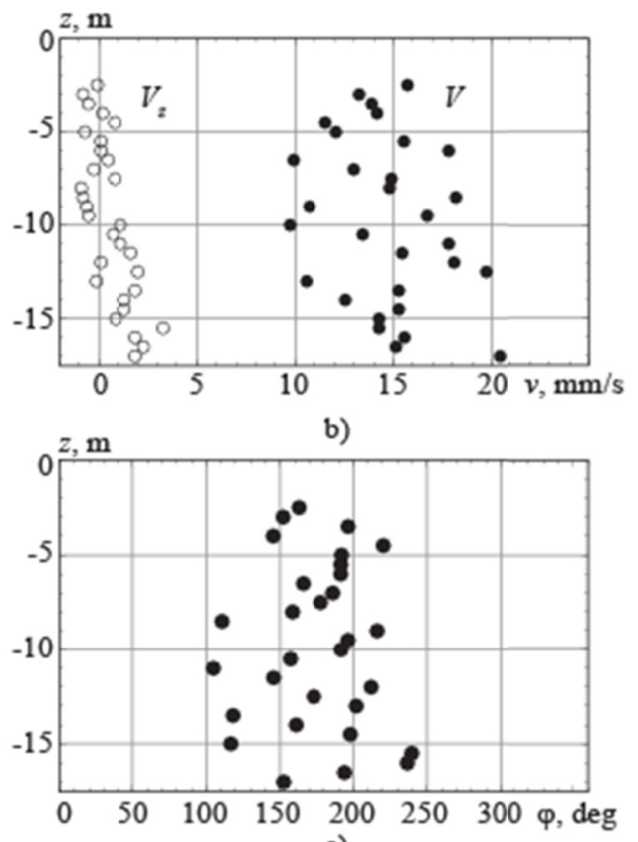

c)

Figure 9. Scheme of the ADCP deployment on March 30, 2014 (a). Profiles of vertical water velocity $\left(V_{z}\right)$ absolute velocity $(V)(b)$, and velocity direction (c)

\section{Discussion}

Comparison of the measured water temperature with the freezing point temperature was performed using the formula (Millero and Leung, 1976)

$$
T_{f}=S(-57.5+1.710523 \cdot \sqrt{S}-0.2154996 \cdot S)
$$

where the freezing point $T_{f}$ is in $\mathrm{mK}$, and water salinity $S$ is in psu. Deviation of the actual temperature from the freezing point was calculated using the formula

$$
\Delta T=T-T_{f}(S)
$$

where $T$ and $S$ are the actual values of the water temperature and salinity measured during CTD profiling. The influence of pressure on the freezing point is ignored because of small water depths.

The CTD profiling performed with SBE-37M in 2011 (Fig. 4d) shows that the water temperature was very close to the freezing point over the entire water column but still it was higher than the freezing point by $0.02-0.03^{\circ} \mathrm{C}$. Figure 10a shows vertical profiles of the temperature deviations $\Delta T_{i}(z) \quad(i=2-4)$ calculated from the data of downcasts 2-4 performed in 2013. Supercooling up to $0.2^{\circ} \mathrm{C}$ was observed during downcast 2 at depths smaller than $5 \mathrm{~m}$. Downcast 3 shows supercooled water above $10 \mathrm{~m}$ depth with maximum supercooling $0.35^{\circ} \mathrm{C}$. Downcast 4 shows supercooled water above $7 \mathrm{~m}$ depth with maximum supercooling $0.35^{\circ} \mathrm{C}$. The maximum supercooling was observed at a depth of $3 \mathrm{~m}$ in all casts. Temperature of the water at the entrance to Rinders Bay was above its freezing point over entire water column in 2013. CTD profiling performed near Paulabreen wall in 2014 shows that the water temperature is higher than its freezing point by $0.1{ }^{\circ} \mathrm{C}$ over entire water column (Fig. 8a). 


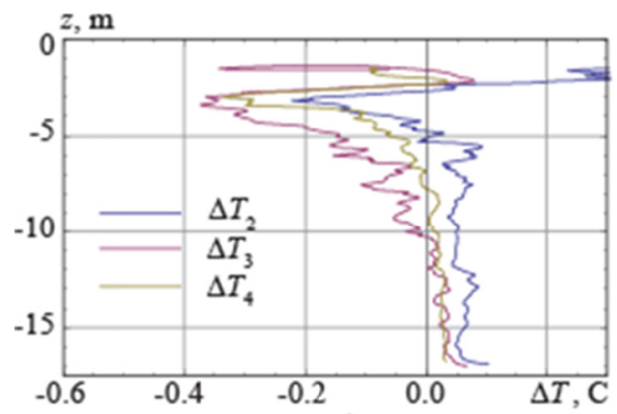

a)

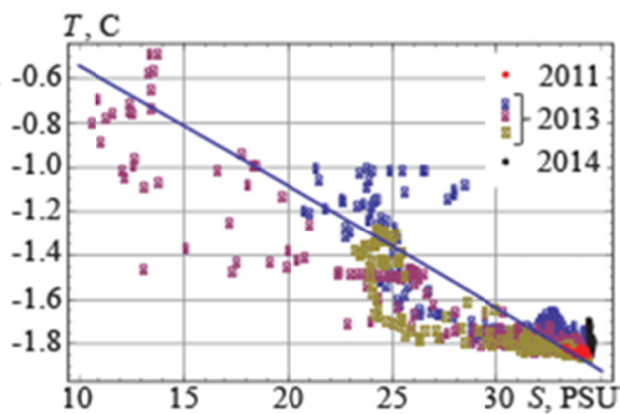

b)

Figure 10. Vertical profile of deviations of the actual temperature from the freezing points versus water depth in (downcasts 2-4 on March 12, 2013) (a). Results of CTD profiling performed in 2011, 2013, and 2014 on a $T$-S plane (b). The blue solid line in Fig. 10b shows freezing temperature versus salinity (Millero and Leung, 1976)

The temperature-salinity dependence near the front of the glacier based on the CTD data is shown in Fig. 10b, along with the freezing temperature as a function of salinity. The graph shows CTD downcasts made in 2011, 2013 and 2014. It is clear that the effect of supercooling is related to the formation of a layer of freshened water below the ice. We think that freshened water being at the freezing point is leaking from under Paulabreen at the locations where the glacier bed has depressions collecting drained fresh water from the glacier. The water flux from under the glacier is confirmed by the observed upward water flux with velocities 1-3 mm/s (Fig. 9b). Vertical water velocities providing tidal elevation of the water level 1-2 m over 6 hours are much lower.

The temperature of the glacier wall in seawater is close to the water temperature, but we assume that when melting freshwater flows from the glacier the water temperature is close to $0^{\circ} \mathrm{C}$. However, this freshwater appears in the periglacial fjord environment with a temperature close to $-1.8^{\circ} \mathrm{C}$. Vertically homogeneous water facilitates the upward motion of fresh water from the glacier. While ascending to the surface the freshwater cools to the temperatures below its freezing point due to the contact with the surrounding seawater. This temperature $\left(-1.8^{\circ} \mathrm{C}\right)$ is close to the freezing point of seawater with a salinity of 33 , and is well below the freezing temperature of freshwater. The salinity of the water flowing from the glacier is close to zero. A scheme of measurements near the glacier is shown in Fig. 11.

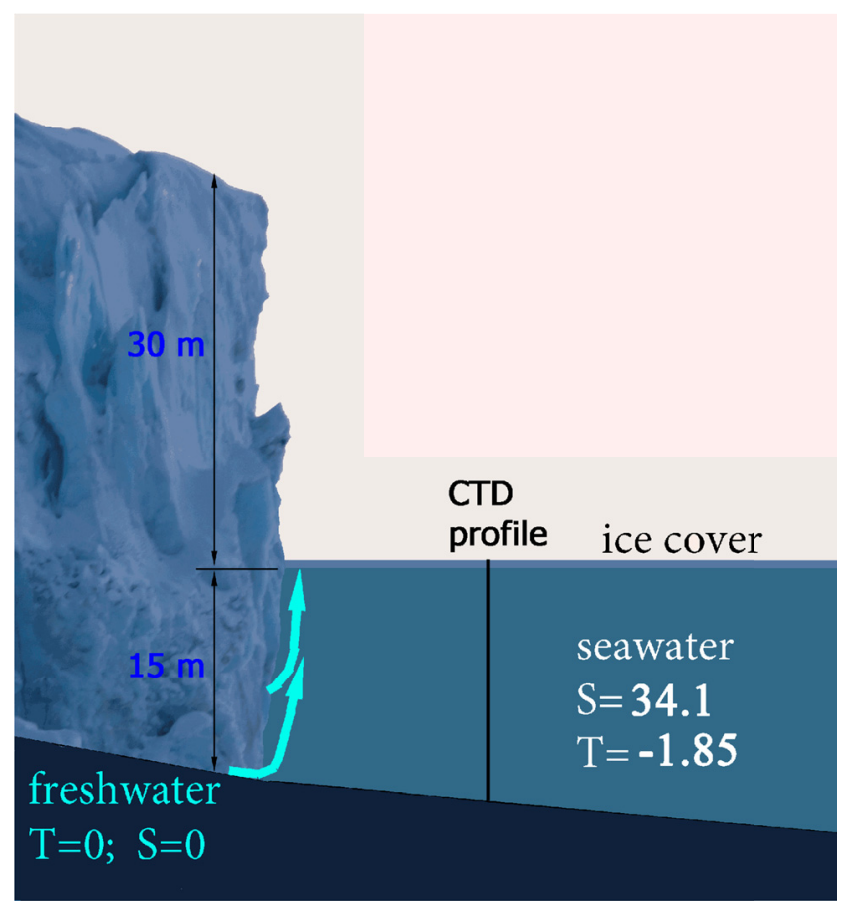

Figure 11. A scheme showing freshwater flow from the glacier, measurement site, and water properties near the glacier front 
Internal melting is observed in polythermal glaciers, which have a mixed basal thermal regime consisting of both warm ice $\left(\right.$ at $0^{\circ} \mathrm{C}$ ) and cold ice (below $0^{\circ} \mathrm{C}$ ). These glaciers consist of an upper layer with cold ice and a lower layer of warmer ice that also contains water. In Spitsbergen there are many such glaciers that descend all the way to the sea (Macheret, 2006; Macheret and Zhuravlev, 1982, Kristensen and Benn, 2012). The mean water content in the lower warmer layer of such glaciers can exceed $0.1 \%$. Some of the accumulated fresh water in this layer can freeze at the boundary between the cold and warm ice, while some of it can flow into the sea even in the winter period (Macheret and Glazovsky, 2000). Schemes and explanation of freshwater flows from polythermal glaciers are given in (Hambrey and Glasser, 2012) and (Moorman, 2003).

The greatest concavities of the glacier wall are found in the deepest places along the front of Paulabreen. This makes us think that the glacier is most subjected to the loss of its mass in these places. Water flux from under the glacier can influence the sediment transport from the glacier bed, make the cohesion between the ice and soil weaker and contribute to the formation of local ice stresses and crevasses.

Mixing of freshened water at the freezing point with colder sea water can influence the formation of supercooled water if the sea water temperature is close enough to its freezing point. The weather in February and March 2013 was very cold with air temperatures close to $-25--30^{\circ} \mathrm{C}$, and therefore entire water column below the ice was almost at the freezing point in relatively shallow places in Spirsbergen fjords. This weather factor is important for the explanation of the observations in March 2013.

The measurements in 2013 were performed at a distance of $10-15 \mathrm{~m}$ from the glacier wall, while the measurements in 2011 and 2014 were performed at a distance of about $100 \mathrm{~m}$ from the glacier wall. The value of supercooling depends on the proportion of sea and fresh water in a unit volume of mixed water. Therefore the value of supercoiling is higher in the immediate vicinity of the glacier wall where the concentration of cold freshened water at the freezing point is higher.

Freshwater freezing in seawater develops in the form of ice crystals, which flow to the surface (Tweed et al., 2005). In the natural conditions such crystals reach the lower surface of the ice cover and increase the ice thickness. Measurements of the ice thickness show that ice thickness increases closer to the glacier. In addition, when we observe the water surface in the holes, which we drill in the ice to lower our instruments, ice crystals very quickly appear at the water surface in the holes drilled near the glacier (provided that the hole is initially cleared of snow and remains of the drilled ice). In 15-20 minutes the water surface in the hole can be covered with a layer of wet crystals approximately one centimeter thick. This phenomenon is not observed far from the glacier.

\section{Conclusions}

We found supercooled water near the front of Paulabreen in Spitsbergen. Analysis of vertical profiles of seawater temperature and salinity close to the front of Paulabreen in Rinders Bay demonstrated the presence of supercooled water with lower salinity than the surrounding water in the fjord. Such water was found at a depth range of 2 to $5 \mathrm{~m}$, while the total depth near the glacier was $17 \mathrm{~m}$. The water was supercooled up to $0.35^{\circ} \mathrm{C}$ at 3 $\mathrm{m}$ depth, an effect related to glaciohydraulic supercooling. We attribute this to the fact that meltwater that contains in the polythermal glacier flows from the glacier in the places of depressions of glacier bed into the seawater and cools by the surrounding water of lower temperature to the temperatures lower than the freezing temperature.

\section{Acknowledgments}

The work was supported by the Project of the Norwegian Research Council "Experiments on Waves in Oil and Ice" (grant 233901) and Russian Science Foundation (grant 14-50-00095).

\section{References}

Błaszczyk, M., Jania, J. A., \& Hagen, J. O. (2009). Tidewater glaciers of Svalbard: Recent changes and estimates of caving fluxes. Polish Polar Research, 30(2), 85-142.

Bogorodsky, P. V., Makshtas, A. P., Marchenko, A. V., \& Kustov., V. Yu. (2014). The role of coal pollution in intensification of the fast ice melting in the Sveabukta bay (Van Mijenfjorden, Spitsbergen). Ice and Snow. 1, 125-130.

Brewster, R. A., \& Gebhart, B. (1994). The effects of supercooling and freezing on natural convection in seawater. International Journal of Heat and Mass Transfer, 37, 543-552.

Cook, S. J., Waller, R. I., \& Knight, P. G. (2006). Glaciohydraulic supercooling: the process and its significance. Progress in Physical Geography, 30, 1-12. 
Creyts, T. T., \& Clarke, G. K. C. (2010). Hydraulics of subglacial supercooling: Theory and simulations for clear water flows. J. Geophys. Res., 115, F03021. http://dx.doi.org/10.1029/2009JF001417

Debenham, F. (1965), The glacier tongues of McMurdo Sound. Geogr. J., 131, 369-371.

Dmitrenko, I. A., Wegner, C., Kassens, H., Kirillov, S. A., Krumpen, T., Heinemann. G., Helbig, A., Schröder, D., Hölemann, J. A., Klagge, T., Tyshko, K. P., \& Busche, T. (2010). Observations of supercooling and frazil ice formation in the Laptev Sea coastal polynya. J. Geophys. Res., 115, C05015. http://dx.doi.org/10.1029/2009JC005798, 2010.

Foldvik, A., \& Kvinge, T., (1974). Conditional instability of sea water at the freezing point. Deep Sea Research, 21, 169-174.

Hagen, J. O., Liestøl, O., Roland, E., \& Jørgensen, T., (1993). Glacier Atlas of Svalbard and Jan Mayen. Norsk Polarinstitutt Meddelelser 129, Oslo: 141 pp.

Hambrey, M. J., \& Glasser, N. F. (2012). Discriminating glacier thermal and dynamic regimes in the sedimentary record. Sedimentary Geology, 251-252, 1-33.

Hoyland, K. (2009). Ice thickness, growth and salinity in Van Mijenfjorden, Svalbard, Norway. Polar Research, $28,339-352$.

Huppert, H. E., \& Turner, J. S. (1980). Ice blocks melting into a salinity gradient. J. Fluid Mechanics, 100, 367-384.

Jacobs, S. S., Huppert, H. E., Holdsworth, G., \& Drewry, D. J. (1981). Thermohaline steps induced by melting of the Erebus Glacier Tongue. J. Geoph. Res., 86(C7), 6547-6555.

Jeffries, M. O., \& Weeks, W. F. (1992). Structural characteristics and development of sea ice in the 15 Western Ross Sea. Antarct. Sci., 5, 63-75.

Jiskoot, H., Murray, T., \& Boyle, P. (2000). Controls on the distribution of surge-type glaciers in Svalbard. Journal of Glaciology, 46(154), 412-422.

Josberger, E. G., \& Martin, S. (1981). Convection generated by vertical icewalls. J. Fluid Mechanics, 111, 439-473.

Karulina, M., Karulin, E., \& Marchenko, A. (2013). Field investigations of first-year ice mechanical properties in North-West Barents Sea. Proc. Int. Conf. Port Ocean Eng. Arct. Cond., POAC13-049. Espoo, Finland, 11.

Kristensen, L., \& Benn, D. I. (2012). A surge of the glaciers Skobreen-Paulabreen, Svalbard, observed by time-lapse photographs and remote sensing data. Polar Research, 31, 11106, http://dx.doi.org/10.3402/polar.v31i0.11106

Lawson, D. E., Strasser, J. C., Evenson, E. D., Alley, R. B., Larson, G. J., \& Arcone, S. A. (1998). Glaciohydraulic supercooling: a freeze-on mechanism to create stratified, debris-rich basal ice: I. Field evidence. J. Glaciology, 44, 547-562.

Macheret, Y. Y. (2006). Radiosounding of Glaciers. Moscow, Nauchnyi Mir.

Macheret, Y. Y., \& Glazovsky, A. F. (2000). Estimation of absolute water content in Spitsbergen glaciers from radar sounding data. Polar Research, 19, 205-216.

Macheret, Y. Y., \& Zhuravlev, A. B. (1982). Radio-echo sounding of Svalbard glaciers. J. Glaciology, 28, 295-314.

Marchenko, A., Langen, I., \& Shestov, A. (2009). Hydrological characteristics of a narrow and shallow part of Van Mijen fjord on Spitsbergen. Proceedings of Nineteenth (2009) International Offshore and Polar Engineering Conference (ISOPE). Osaka, Japan, June 21-26, TCP-689.

Marchenko, A., Shestov, A., Karulin, E., Morozov, E., Karulina, M., Bogorodsky, ... Makshtas, A. (2011). Field studies of sea water and ice properties in Svalbard fjords. Proc. Int. Conf. Port Ocean Eng. Arct. Cond., POAC11-148, Montreal, Canada, 13 pp.

Millero, F. J., \& Leung, W. H. (1976). Thermodynamics of seawater at one atmosphere. American Journal of Science, 276, 1035-1077.

Moorman, B. (2003). Glacier-permafrost hydrology interactions, Bylot Island, Canada. Proceedings 8th International Permafrost Conference, Zurich, Switzerland, Phillips, M., Springman, S.M., Arenson, L. (Eds), A. A. Balkema Publishers, 783-788. 
Nansen, F. (1897). Fram over Polhavet. Den norske polarfcerd 1893-1896. Aschehoug, Kristiania.

Robinson, N. J., Williams, M. J. M., Barrett, P. J., \& Pyne, A. R. (2010). Observations of flow and ice--ocean interaction beneath the McMurdo Ice Shelf, Antarctica. J. Geophys. Res., 115, C03025, doi:10.1029/2008JC005255.

Röthlisberger, H. (1972). Water pressure in intra- and subglacial channels, J. Glaciol., 11, 177-203.

Skogseth, R., Nilsen, F., \& Smedsrud, L.H. (2009). Supercooled water in an Arctic polynya: observations and modeling. J. Glaciology, 55, 43-52.

Stevens, C. L., Stewart, C. L., Robinson, N. J., Williams, M. J. M., \& Haskell, T. G. (2010). Flow and mixing around a glacier tongue. Ocean Sci., 7, 293-304.

Tweed, F. S., Roberts, M. J., \& Russell, A. J. (2005). Hydrologic monitoring of supercooled discharge from Icelandic glaciers. Quaternary Science Reviews, 24, 2308-2318.

Zatsepin, A. G., \& Golovin, P. N. (2001). Laboratory experiments on frazil ice formation with application to the Arctic marine environment. Memoirs of National Institute of Polar Research (Tokyo), Special Issue, 54, 417-421.

\section{Copyrights}

Copyright for this article is retained by the author(s), with first publication rights granted to the journal.

This is an open-access article distributed under the terms and conditions of the Creative Commons Attribution license (http://creativecommons.org/licenses/by/4.0/). 